\begin{tabular}{c} 
LOSARI: Jurnal Pengabdian Kepada Masyarakat \\
http://ojs.losari.or.id/index.php/losari \\
Volume 1 | Nomor 2| Desember |2019 \\
e-ISSN: 2684-8678 dan p-ISSN: 2684-9887 \\
\hline EOS4RT
\end{tabular}

\title{
Pelatihan Akuntansi Berbasis Komputer dalam Ruang Lingkup Pengelola Koperasi se-Kota Makassar
}

\author{
Anwar $^{1}$, Faisal Arif ${ }^{1}$, Muhammad Ikram Marham Januanto ${ }^{1}$
}

\author{
Keywords : \\ Zahir Accounting; \\ Akuntansi Koperasi;

\section{Corespondensi Author} \\ ${ }^{1}$ Program Studi Akuntansi, STIEM \\ Bongaya \\ Email: anwar@stiem-bongaya.ac.id
}

\section{History Artikel}

Received: September 2019

Reviewed: September 2019

Revised: Oktober 2019

Accepted: November 2019

Published: Desember 2019

\begin{abstract}
Abstrak. Tujuan pengabdian kepada masyarakat ini untuk memberikan edukasi kepada peserta pelatihan mengenai pentingnya sistem akuntansi berbasis komputer dan membrikan pelatihan penginputan data keuangan kedalam sistem akuntansi berbasis komputer dan simulasi peembuatan laporan keuangan berbasis komputer. Kegiatan ini dilaksanakan dalam bentuk seminar dan pelatihan akuntansi berbasis komputer dengan menggunakan software akuntansi Zahir Accounting. Hasil kegiatan pelatihan akuntansi berbasis komputr dalam ruang lingkup pengelola koperasi se-Kota Makassar dapat dikatakan berhasil. Hal ini dapat dilihat dari persentase khadiran peserta da antusiasme peserta sealma berjalannya kegiatan.
\end{abstract}

(i) This work is licensed under a Creative Commons Attribution

4.0 International License

\section{PENDAHULUAN}

Berdasarkan Peraturan Daerah Kota Makassar Nomor 3 tahun 2009 tentang Pembentukan Susunan Organisasi dan Tata Kerja Dinas Koperasi dan Usaha Kecil Menengah (UKM) Kota Makassar mempunyai tugas pokok membantu walikota dalam merumuskan, membina dan mengendalikan kebijakan dibidang perkoperasian, adapun fungsi usaha kecil menengah yaitu:

1) Menyusun rumusan kebijakan teknis dibidang Koperasi, Usaha Kecil Menengah

2) Merumuskan rencana dan program pengaturan, pengurusan pendaftaran pengesahan serta pembubaran

3) Melaksanakan pengendalian dan perencanaan teknis operasional penyuluhan Koperasi

4) Menyusun rencana pembinaan pengelola Koperasi Simpan Pinjam

5) Memberikan perizinan dan pelayanan umum dibidang perkoperasian serta

6) Membina unit pelaksana teknis.
Dengan peraturan daerah ini, maka kedudukan Dinas Koperasi dan Usaha Kecil Menengah Kota Makassar merupakan unsur pelaksana Pemerintah Kota yang dipimpin oleh seorang Kepala Dinas yang berada dibawah dan bertanggung jawab kepada Walikota melalui Sekretaris Daerah. Berdasarkan fungsi di atas, Dinas Koperasi dan UKM Kota Makassar diharuskan membuat program kerja yang efektif, salah satunya melalui seminar dan pelatihan akuntansi berbasis komputer, yang bertujuan untuk meningkatkan kinerja pengurus koperasi yang ada di kota makassar dalam hal tata kelola keuangan yang akuntabel.

Perkembangan era globalisasi dewasa ini yang begitu pesat, dimana persaingan bisnisnya juga semakin ketat, diperlukan sebuah strategi untuk bisa mempertahankan kelangsungan hidup dan memajukan suatu perusahaan agar tidak tertinggal dengan yang lain. Hal ini tidak hanya berlaku bagi private sector yang berorientasi pada laba, tetapi juga berlaku untuk public sector yang berorientasi pada efisiensi \& efektivitas kinerja. 
Laporan keuangan merupakan informasi tentang kondisi perusahaan kepada pihak internal maupun pihak eksternal perusahaan. Hal ini dianggap penting karena laporan keuangan merupakan komponen terpenting dalam pengambilan keputusan.

Sistem informasi akuntansi bertujuan untuk menghasilkan laporan keuangan. Untuk mengefisienkan aktifitas perusahaan yang semakin kompleks, maka perusahaan harus berpindah dari metode manual atau sederhana ke metode komputerisasi (Hidayat dan Sugiarto, 2012). Dengan demikian maka perusahaan memerlukan suatu sistem informasi akuntansi yang dapat bekerja dengan kecepatan dan ketepatan tinggi yang dikenal dengan Sistem Akuntansi Berbasis Komputer

Dengan adanya sistem akuntansi berbasis komputer, tidak akan membutuhkan banyak waktu, biaya dan tenaga dalam mengerjakannya bila dibandingkan dengan pengerjaan secara manual/tradisional. Selain itu, informasi yang dihasilkan oleh sistem akuntansi berbasis komputer akan menjadi lebih akurat dan tidak terlalu banyak melakukan kroscek secara berulang terhadap output/laporan keuangan yang dihasilkan

Sistem akuntansi berbasis komputer mampu mempermudah pekerjaan sumber daya manusia dan untuk menghasilkan laporan keuangan yang lebih cepat, akurat, dan relevan bagi perusahaan. Bahkan banyak ahli piranti lunak berlomba-lomba menciptakan suatu aplikasi software khusus untuk sistem informasi akuntansi yang dijual ke perusahaan-perusahaan untuk menghasilkan laporan keuangan. Salah satu software akuntansi yang dapat menghasilkan laporan keuangan yang cepat dan akurat yaitu Zahir Accounting.

Zahir Accounting merupakan salah satu software akuntansi produksi Indonesia yang mampu menjawab kebutuhan diatas. Zahir Accounting merupakan sebuah software bisnis finansial terbaik dan termurah untuk digunakan, memiliki fasilitas lengkap dan dapat diandalkan, dirancang untuk memnuhi kebutuhan pengusaha, dibuat dari sudut pandang pengusaha, sehingga setiap pengusaha dapat mengelola dan memiliki kendali penuh terhadap usahanya.

\section{Definisi Sistem Informasi}

Davis dan Olson (1985) mengemukakan Informasi merupakan data yang diproses lebih jauh sehingga mempunyai arti bagi sipenerima dan mempunyai "nilai pengaruh" atas tindakantindakan, keputusan-keputusan sekarang atau masa yang akan datang. Agar dapat menghasilkan informasi yang diharapkan, maka diperlukan suatu sistem yang mangatur arus dan pengelolaan data akuntansi dalam perusahaan, untuk itu perlu adanya seorang yang cakap dan memiliki kemampuan untuk mengoperasikan komputer sebagai penunjang pengolahan data akuntansi guna memberikan informasi yang diperlukan oleh perusahaan.

Informasi Akuntansi yang dihasilkan dari suatu sistem dibedakan menjadi dua, yakni :

1. Informasi akuntansi keuangan

2. Informasi akuntansi manajemen.

Akuntansi Keuangan disusun terutama untuk menghasilkan informasi, biasanya dalam bentuk laporan keuangan yang ditujukan kepada pihak-pihak luar perusahaan. Umumnya laporan keuangan menurut Standar Skuntansi Keuangan (SAK) terdiri dari :

1. Neraca

2. Laporan Laba Rugi

3. Laporan Arus Kas

4. Laporan Perubahan Ekuitas

5. Catatan Atas Laporan Keuangan

Laporan-laporan ini merupakan ringkasan dari keadaan perusahaan dan hasil kegiatannya ditujukan kepada pihak luar perusahaan yang mempunyai kepentingan terhadap perusahaan seperti pemegang saham, kreditur, pemerintah dan masyarakat pada umunya. Oleh karena laporan ini ditujukan kepada pihak luar perusahaan, cara penyajian dan isinya diatur oleh Standar Pemeriksaan Akuntan Publik (SPAP).

Reformasi manajemen keuangan negara, ditandai dengan diluncurkannya satu paket perundang-undangan bidang keuangan negara yakni UU Nomor 17 Tahun 2003 tentang Keuangan Negara, UU Nomor 1 Tahun 2004 tentang Perbendaharaan Negara dan UU Nomor 15 Tahun 2004 tentang Pemeriksaan Pengelolaan dan Tanggung Jawab Keuangan Negara) membawa implikasi diperlukannya sistem pengelolaan keuangan negara yang transparan dan akuntabel. Kegiatan perencanaan, pelaksanaan, pengawasan, dan pertanggungjawaban pengelolaan keuangan 
Anwar, Faisal Arif, Ikram Marham. Pelatihan akuntansi berbasis komputer dalam ruang lingkup pengelola Koperasi se-Kota Makassar

negara harus dilaksanakan dengan tertib, terkendali, efisien dan efektif.

Upaya konkrit mewujudkan akuntabilitas dan transparansi dilingkungan pemerintah, mengharuskan setiap pengelola keuangan negara menyampaikan laporan pertanggung jawaban pengelolaan keuangan dengan cakupan yang lebih luas dan tepat waktu. Laporan harus disajikan dalam bentuk Laporan Keuangan yang disusun berdasarkan proses akuntansi dan disajikan sesuai dengan Standar Akuntansi Pemerintahan (SAP) sesuai dengan Peraturan Pemerintah Nomor 71 Tahun 2010 tentang Standar Akuntansi Pemerintahan

Berdasarkan UU No. 25 tahun 1992 pasal 35 laporan keuangan yang terdapat pada dinas koperasi, terdiri atas:

1. Neraca

2. Perhitungan Hasil Usaha

3. Catatan Atas Laporan Keuangan

Dari ketiga komponen laporan keuangan diatas, SAK ETAP menambahkan dua komponen, yaitu:

1. Laporan Perubahan Ekuitas

2. Laporan Arus Kas

\section{Sistem Informasi Akuntansi}

Menurut Bodnar dan Hopwood (2000:6), sistem informasi akuntansi adalah sebuah sistem yang berbasis komputer yang dirancang untuk mengubah data akuntansi menjadi suatu informasi, lebih luas lagi istilah sistem informasi akuntansi yang termasuk di dalamnya adalah siklus pemrosesan transaksi, pemakaian teknologi, dan pengembangan sistem informasi. Sedangkan definisi lain tentang sistem informasi akuntansi adalah sebuah sistem yang memproses data dan transaksi untuk menghasilkan suatu informasi yang bermanfaat untuk merencanakan, mengendalikan, dan mengoperasikan bisnis perusahaan (Krismiaji, 2002:4). Dengan demikian, sistem informasi akuntansi harus:

1. Mengumpulkan transaksi-transaksi dan data lain serta memasukkan ke dalam suatu sistem

2. Memproses data transaksi

3. Menyimpan data untuk keperluan di masa yang akan datang

4. Menghasilkan suatu informasi yang diperlukan dengan cara memproduksi laporan, atau memungkinkan para pemakai untuk melihat sendiri data yang tersimpan di dalam komputer
5. Mengendalikan seluruh proses sedemikian rupa sehingga suatu informasi yang dihasilkan bisa akurat dan dapat dipercaya.

Dengan demikian, sistem informasi akuntansi berbasis komputer dapat diartikan sebagai proses pengelolaan data/transaksi, yang dimulai dari mulai penginputan data, kemudian penyimpanan dan pemrosesan data, sehingga dapat menghasilkan suatu laporan keuangan yang dibutuhkan oleh pihak yang berkepentingan dengan menggunakan sistem komputerisasi. Secara garis besar, proses tersebut digambarkan dalam bagan berikut ini:

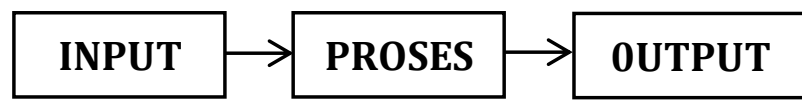

Untuk itu perlu dititik beratkan pada peranan penerapan sistem informasi akuntansi yang berbasis komputer dalam pengelolaan data yang menyeluruh dan terpadu dalam suatu sIstem akuntansi untuk berbagai bagian dalam perusaaan sangat diperlukan guna keperluan perusahaan untuk menilai sejauh mana keberhasilan perusahaan dalam melakukan kegiatan perusahaan dan kepentingan seorang top manajemen dalam pengambilan keputusan.

Sistem informasi akuntansi berbasis computer yang mamu memudahkan dalam penyusunan laporan keuangan menjadi kebutuhan mendasar bagi setiap perusahaan

\section{METODE}

\section{Desain Kegiatan}

Dalam pelaksanaan kegiatan pengabdian masyarakat ini dilakukan dengan bentuk seminar dan pelatihan akuntansi berbasis komputer dengan menggunakan software akuntansi Zahir Accounting.

Tehnik Atau Metode Kegiatan

Kegiatan ini dilaksanakan dalam bentuk seminar dan pelatihan akuntansi berbasis komputer.

\section{Rencana Tempat/Lokasi dan Waktu Pelaksanaan}

Seminar dan pelatihan akuntansi berbasis komputer dilaksanakan di hotel LA'RIZ Wthree Lagaligo Makassar Continent pada tanggal 2223 November 2019.

\section{HASIL DAN PEMBAHASAN Laporan Hasil Kegiatan}

Kegiatan pelatihan komputerisasi untuk pengelola koperasi dalam ruang lingkup kota 
Anwar, Faisal Arif, Ikram Marham. Pelatihan akuntansi berbasis komputer dalam ruang lingkup pengelola Koperasi se-Kota Makassar

Makssar, dilaksanakan pada hari rabu tanggal 15 Maret 2017. Kegiatan dimulai pukul 09.00 sampai dengan pukul 12.00 wita. Kegiatan diawali dengan registrasi peserta di ballroom hotel Continent yang sekaligus sebagai tempat pelatihan. Peserta yang registrasi berjumlah 29 orang, yang terdiri dari peserta berjenis kelamin laki-laki 19 orang dan berjenis kelamin perempuan 10 orang.

Kegiatan ini diawali dengan pembukaan oleh kepala Dinas Koperasi Kota Makassar, kemudian dilanjutkan dengan sesi pertama yaitu seminar yang dibawakan oleh Anwar S.E., M.Si dibantu dengan Muhammad Ikram Marham Januanto S.E., M.Si., Ak. menyampaikan hal-hal yang berkaitan dengan pentingnya pembuatan laporan keuangan berbasis komputer pada organisasi sektor publik seperti koperasi.

Pada sesi kedua yaitu pelatihan akuntansi berbasis komputer menggunakan software Zahir Accounting dengan pemateri Faisal Arief S.E., M.Si., Ak., CA. dan Muhammad Ikram Marham Januanto S.E., M.Si., Ak. bertindak sebagai operator. Dalam sesi ini peserta diajarkan bagaimana menggunakan software Zahir Accounting mulai dari menginput saldo awal, menginput transaksi dan menampilkan laporan keuangan hingga bagaimana cara dalam membaca informasi yang terdapat dalam laporan keuangan.

Hasil kegiatan pelatihan akuntansi berbasis komputer dalam ruang lingkup pengelola koperasi se-Kota Makassar dapat dikatakan berhasil. Hal ini dapat dilihat dari persentase kehadiran peserta dan antusiasme peserta selama berjalannya kegiatan.

\section{Pembahasan}

Kegiatan pelatihan akuntansi berbasis komputer dalam ruang lingkup pengelola koperasi se-kota Makassar dapat berjalan dengan lancar. Pelatihan akuntansi berbasis komputer memang sangat dibutuhkan bagi pengelola koperasi, kebanyakan peserta mengeluhkan kurangnya pengetahuan dan pemahaman akan pengoperasian komputerisasi akuntansi dan arti pentingnya untuk meningkatkan kualitas dan akuntabilitas pelaporan keuangan. Pengelola koperasi menyadari sepenuhnya bahwa komputerisasi akuntansi penting bagi mereka dalam membuat laporan keuangan. Pengelola koperasi bertanggungjawab atas laporan keuangan yang dibuatnya sehingga harus menjaga kualitas laporannya. Dalam hal ini diperlukan sebuah perangkat lunak agar dapat mempermudah pembuatan laporan keuangan dan meningkatkan kualitas pelaporan dengan menerapkan sistem komputerisasi.

Pengelola koperasi hendaknya bertanggungjawab atas laporan keuangan yang dibuatnya. Sehingga laporan yang dibuatnya dapat mencerminkan keadaan yang sebenarnya, sehingga anggota koperasi mendapatkan informasi yang berkualitas dan akuntabilitas. Agar laporan yang dibuatnya berkualitas maka sebaiknya dalam pembuatan laporan keuangan menerapkan akuntansi berbasis komputer.

Akuntansi berbasis komputer dijadikan materi pelatihan agar pengelola koperasi dapat dengan mudah menyusun laporan keuangan dan menghasilkan pelaporan yang berkualitas, sehingga akan memberikan informasi kepada para anggota koperasi yang mencerminkan keadaan yang sebenarnya. 
Anwar, Faisal Arif, Ikram Marham. Pelatihan akuntansi berbasis komputer dalam ruang lingkup pengelola Koperasi se-Kota Makassar

Gambar Kegiatan
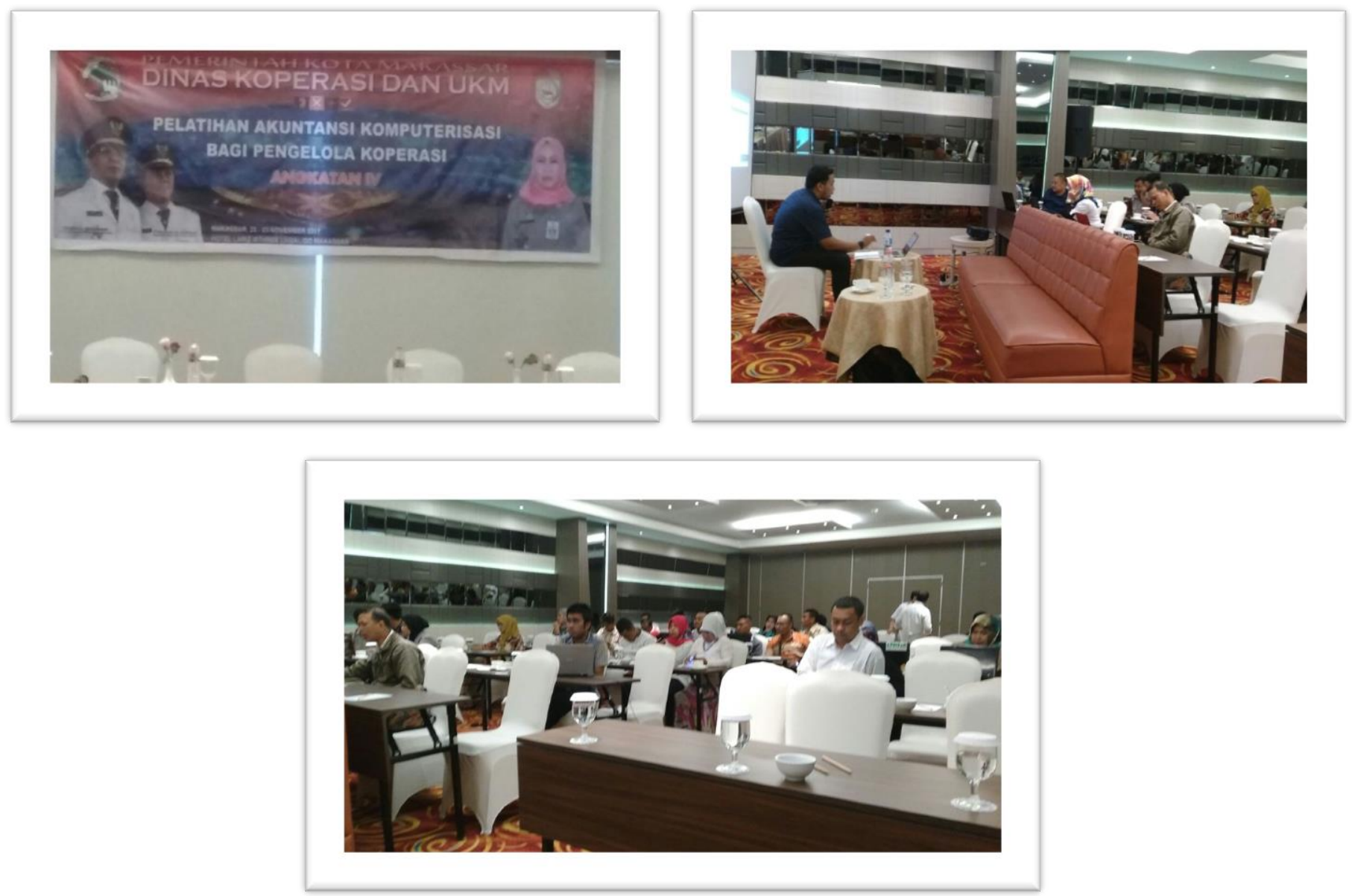

Gambar 1. Tim Memberikan Materi dalam Pelatihan Akuntansi Komputerisasi Koperasi

\section{Simpulan Dan Saran}

\section{Kesimpulan}

Berdasarkan uraian hasil dan pembahasan di atas, maka dapat disimpulkan bahwa:

1. Terdapat respon positif terhadap kegiatan ini mengingat kegiatan pengabdian merupakan kebutuhan pengelola koperasi dalam rangka peningkatan mutu dalam pembuatan laporan keuangannya.

2. Tanggapan peserta terhadap pelaksanaan kegiatan pelatihan akuntansi berbasis komputer ini sangat baik. Hal ini dapat dilihat dari jumlah peserta yang hadir dan antusias peserta selama mengikuti kegiatan dari awal sampai akhir.

\section{Saran}

Berdasarkan evaluasi yang telah dilakukan dapat diajukan beberapa saran sebagai berikut:

1. Waktu pelaksanaan kegiatan pengabdian perlu ditambah agar tujuan kegiatan dapat tercapai sepenuhnya.

2. Penyediaan perangkat komputer atau laptop sebagai penunjang dalam kegiatan agar pelaksanaan kegiatan dapat maksimal. 
Anwar, Faisal Arif, Ikram Marham. Pelatihan akuntansi berbasis komputer dalam ruang lingkup pengelola Koperasi se-Kota Makassar

\section{Daftar Rujukan}

Bodnar, H. George dan William S. Hopwood. 2000. Sistem Informasi Akuntansi. Buku I, Edisi Ke-6. Penerjemah Amir Abadi Jusuf dan Rudi M. Tambunan, Salemba Empat. Jakarta.

Davis, Gordon B. dan Margrethe H. Olson, 1985, Kerangka Dasar Sistem Informasi, Edisi Kedua, Pustaka Binaman Pressindo, Jakarta.

Hidayat A, Sugiarto. 2012. Penerapan Sistem Informasi Akuntansi Berbasis Komputer pada Kopinsek PT. Sucofindo Cabang Medan. JWEM STIE Mikroskil. Vol 2 Nomor 1.

Ikatan Akuntan Indonesia (IAI). 2013. Standar Profesional Akuntan Publik. Edisi 4.Cetakan 1. Salemba 4. Jakarta.

Krismiaji. 2002. Sistem Informasi Akuntansi. Jilid 1. Yogyakarta: UPP AMP YKPN.

Peraturan Daerah Kota Makassar Nomor 3 tahun 2009 tentang Pembentukan Susunan Organisasi dan Tata Kerja Dinas Koperasi dan Usaha Kecil Menengah (UKM) Kota Makassar.

Republik Indonesia. 1992. Undang-undang No. 25 tahun 1992 Tentang Perkoperasian.

Republik Indonesia. 2003. Undang-undang No. 17 tahun 2003 Tentang Keuangan.

Republik Indonesia. 2004. Undang-undang No. 1 tahun 2004 Tentang Perbendaharaan Negara.

Republik Indonesia. 2004. Undang-undang No. 15 tahun 2004 Tentang Pemeriksaan Pengeloaan dan Tanggung Jawab Keuangan Negara.

Republik Indonesia. 2005. Peraturan Pemerintah Nomor 71 Tahun 2010 Tentang Standar Akuntansi Pemerintahan. 